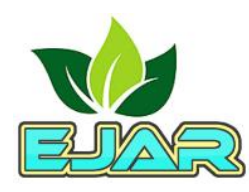

RESEARCH

\title{
The impact of sowing date and nitrogen fertilization on Yield in four bread wheat cultivars
}

\author{
Ibrahim S. Mohamed, Mohamed Mohiy and Mohamed M. Mohamed*
}

Address:

Wheat Research Department, Field Crops Research Institute, Agricultural Research Center, Giza, Egypt.

* Corresponding author: Mohamed M. Mohamed: mmareei@yahoo.com

Received: 07-09-2021; Accepted: 22-12-2021; Published: --02-02-2022

doi: $\underline{10.21608 / \text { ejar.2022.94794.1145 }}$

\section{ABSTRACT}

In the present work, we evaluated four bread wheat cultivars, three nitrogen $(\mathrm{N})$ fertilization amounts, and two planting dates. The experiment was conducted at Almarashda Agricultural Research Station during the 2018-19 and 2019-20 growing seasons to determine the effect of two sowing dates (November 25th and December 25th) and three nitrogen fertilization rates (125, 100, and $75 \mathrm{~kg} \mathrm{~N}$ Fadden-1) on the phenology, grain yield, and grain component composition of four Egyptian bread wheat cultivars (Triticum aestivum, L), namely Sids 14, Shandaweel 1, Giza 171, and Gemm The research employed a split-split plot design with three duplicates. The results indicated that seeding late (25 December) considerably reduced all characters in both seasons when compared to the optimum sowing date ( 25 November), except for 100 -grain weight, which remained the same. All attributes were improved as the $\mathrm{N}$ fertilization level was increased from 75 to $125 \mathrm{~kg} \mathrm{~N}$ Fadden-1. Sids 14 outperformed the other cultivars in practically all evaluated traits including grain yield.

Keywords: Nitrogen fertilization, Sowing date, Triticum aestivum L, yield

\section{INTRODUCTION}

Food security is a necessity for every human in the world, at all places and times, have social, economic and physical access to safe, and suitable food that meets their preferences and food needs for a healthy and active life as defined by the United Nations' Committee on World Food Security (IFPRI, 2021). In the last season 2020-2021, the cultivated area is estimated at 1.4 million hectares, and the Egyptian wheat production approximately 8.9 million tons (FAO, 2020).

The timing of sowing has a significant impact on phenophases, grain production, and wheat components (Kiss et al., 2014). Longer vegetative development phase, as a result of sowing at the approved sowing date, to improve radiation use efficiency and dry matter mobilization (Sun et al., 2013), and thus the optimum values for grain yield and its components (Eslami et al., 2014; Shazma et al., 2015). Late sowing reduces N uptake and buildup in wheat crops in general (Ehdaie and Waines, 2001). The planting date has a significant impact on the grain yield potential of wheat production. Refay (2011) evaluated the impact of early (November 21st) and late (December 21st) seeding on several wheat cultivars grown in North Sinai. His studies found that late sowing resulted in an 8 percent drop in grain output when compared to recommended sowing. They also discovered different responses for wheat cultivars when planting dates were changed. Except for plant height, 1000-kernel weight, and biological yield, the interaction between sowing date, genotypes, and nitrogen fertilizer levels was significant for all parameters (Abdel Nour and Fateh, 2011)

Nitrogen is a critical macronutrient that influences crop vegetative growth, grain yield, and yield components (Tranaviien et al., 2007). (Ali et al., 2011). The influence of $N$ is determined by the rate of addition and the response of the sowed cultivar. Many researchers agreed that raising $\mathrm{N}$ levels resulted in an increase in grain yield and its components (Shah et al., 2011; and Iqbal et al., 2012; and Benin et al., 2012), and they found genetic heterogeneity for wheat cultivars in response to increased rates of $\mathrm{N}$ fertilization. Hefny and Naheif (2018) characters under studied were responded significantly to sowing dates, nitrogen fertilizer levels, genotypes and their first and second-order interactions effect. In Egypt, there is a need to increase wheat productivity to reduce the gap between consumption and production. World wheat production reached about 772 million tons (Shahbandeh, 2021). As of the year 2020, Egypt produced approximately 8.9 million tons of wheat produced from a total harvested area of approximately 1.39 million hectares, Egypt is one of the largest wheat importers in the world (USDA, 2020; Statista, 2021). In light of the limited area and the high prices of production requirements, therefore, the tendency to increase productivity per unit land area. This can be accessed through management of agricultural practices, especially, $\mathrm{N}$ fertilization and sowing date and select wheat cultivars superior in grain yield.

The objectives of this study were to assess the timeliness of spring bread wheat sowing which impact yields and identify the best bread wheat cultivar under different sowing dates and three nitrogen fertilization levels. 


\section{MATERIAL AND METHODS}

Trial location and treatments detail:

This study was carried out during the two successive growing seasons, (2018-2019 and 2019-2020), at Almarashda Agricultural Research Station, Agricultural Research Center, Giza, Egypt $\left(26^{\circ} 05^{\prime} \mathrm{N}\right.$ and $32^{\circ} 28^{\prime}$ E situated at $80 \mathrm{~m}$ elevation).

The sowing dates were November $25^{\text {th }}$ and December $25^{\text {th }}$ and the $\mathrm{N}$ fertilization levels were 75,100 and $125 \mathrm{~kg} \mathrm{~N}$ Fadden $^{-1}$ and the four Egyptian bread wheat cultivars (Sids 14, Shandaweel 1, Giza 171 and Gemmiza 12). Plot size was $4 \mathrm{~m}^{2}$ (5 rows $\times 20 \mathrm{~cm}$ between rows $\times 4 \mathrm{~m}$ length). The sowing method was a hand drill.

Soil, at the experimental sites, was sandy, with $\mathrm{pH} 8$, available $\mathrm{N}=11.3 \mathrm{ppm}$, available $\mathrm{P}=2.50 \mathrm{ppm}$, available $\mathrm{K}=65$, E.C.= $0.31 \mathrm{dS} / \mathrm{m}$ and organic matter $=0.11 \%$, as an average of the two seasons.

\section{Crop management:}

Nitrogen rates in the form of ammonium nitrate were applied in three equal doses at the sowing, tillering, and stem elongation periods ( 33.5 percent $\mathrm{N}$ ). For all kinds, the seeding rate was $90 \mathrm{~kg}$ Fadden-1. All other agricultural procedures advised for wheat production in the region were followed.

\section{Data collection:}

The days to heading, days to maturity, plant height $(\mathrm{cm})$, number of spikes $\mathrm{m}^{-2}$, number of grains spike-1, 100-grain weight $(\mathrm{g})$, biomass $\left(\mathrm{kg} \mathrm{plot}^{-1}\right)$, grain yield $\left(\mathrm{kg} \mathrm{plot}^{-1}\right)$ and straw yield $\left(\mathrm{kg} \mathrm{plot}^{-1}\right)$, were recorded during the experimentation.

\section{Statistical analysis:}

The collected data were statistically analyzed through Genstat computer software program. The treatment means were compared through the least significant difference test at a 5\% probability level according to Gomez and Gomez (1984). Experimental design, in the two seasons, was in a split-split plot with three replications. The main plots were assigned to the two sowing dates, the subplots included the three nitrogen fertilization levels, whereas, the sub-sub-plots included the four bread wheat genotypes. The sub-sub-plot size was $4 \mathrm{~m}^{2}$ ( 5 rows $\times 0.2 \mathrm{~m}$ between rows $\times 4 \mathrm{~m}$ length). The sowing method was a hand drill.

\section{RESULTS}

\section{Sowing date:}

The results indicated that the late sowing date (25 December) significantly decreased all character in both the seasons compared to the recommended sowing date (25 November) except 100-grain weight in the first season Table (3). In terms of grain yield and its components, the results showed that postponing sowing significantly reduced all analyzed grain yield and its features when compared to the suggested sowing date of November $25^{\text {th }}$. In the two consecutive seasons, such dates yielded 340 and $331,55.94$ and $5012,3.00$ and $3.29 \mathrm{~g}, 2.23$ and $2.02 \mathrm{~kg} \mathrm{plot}^{-1}$, and 9.26 and $8.45 \mathrm{~kg}$ plot-1 for number of spikes m-2, number of grains spike1, 100-grain weight, grain yield, and biomass.

\section{Nitrogen ( $\mathrm{N}$ ) fertilization:}

The results of analysis of variance revealed that the nitrogen fertilization levels significantly affected most of the studied characters in the two seasons except 100-grain weight in the second season Table (3). The days to heading and maturity, were less with low levels from nitrogen fertilization, while, the significant increase in all characters with increased $\mathrm{N}$ fertilization level from 75 to $125 \mathrm{~kg} \mathrm{~N} /$ Fadden in the two seasons. Such a high level from nitrogen fertilization gave 2.17 and $1.94 \mathrm{~kg} \mathrm{plot}^{-1}$ for grain yield in the two successive seasons.

\section{Wheat cultivars:}

The bread wheat cultivars significantly affected most of the studied characters except days to heading and days to maturity in the second season Table (3). Wheat cultivar Means, presented in Table (3), indicated that Sids 14 was significantly superior to the other cultivars in most of the studied characters in the two seasons, except a number of spikes $\mathrm{m}^{-2}$ in the first season, number of grain spike ${ }^{-1}$ in the second seasons. The cultivar Giza 171 was significantly earlier in days to heading, whereas Shandawell 1 gave higher plants only in the first season and it was late in maturity in the second season. The cultivar Gemmiza 12 gave the highest number of grains splike ${ }^{-1}$ in the first season whereas Giza 171 gave the highest number in the second season. 
Table 1. Effect of sowing date, $\mathrm{N}$ fertilization levels, wheat cultivars and their interaction on days to heading (DH), maturity (DM), plant height (cm) and grain yield and its component during the two seasons.

\begin{tabular}{|c|c|c|c|c|c|c|c|c|c|c|c|c|c|c|c|c|c|c|}
\hline \multirow[t]{2}{*}{ Treatment } & \multicolumn{2}{|c|}{ DH } & \multicolumn{2}{|c|}{ DM } & \multicolumn{2}{|c|}{ PH } & \multicolumn{2}{|c|}{ \#Grain Spike $^{-1}$} & \multicolumn{2}{|c|}{ \#Spike $\mathrm{m}^{-2}$} & \multicolumn{2}{|c|}{ 100-Grain weight (g) } & \multicolumn{2}{|c|}{ Biomass plot $^{-1}$} & \multicolumn{2}{|c|}{ Straw yield plot ${ }^{-1}$} & \multicolumn{2}{|c|}{ 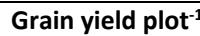 } \\
\hline & S1 & S2 & S1 & S2 & S1 & S2 & S1 & S2 & S1 & S2 & S1 & S2 & S1 & S2 & S1 & S2 & S1 & S2 \\
\hline \multicolumn{19}{|c|}{ Sowing date (D) } \\
\hline $25 / 11 /$ & 62.58 & 64.58 & 99.92 & 99.50 & 103.33 & 96.92 & 55.94 & 50.15 & 340 & 331 & 3.00 & 3.29 & 9.26 & 8.45 & 7.03 & 6.44 & 2.23 & 2.02 \\
\hline $25 / 12 /$ & 50.50 & 57.67 & 91.92 & 92.25 & 84.58 & 86.83 & 49.75 & 44.42 & 223 & 233 & 2.96 & 3.03 & 5.26 & 5.36 & 3.80 & 4.06 & 1.46 & 1.30 \\
\hline $\mathrm{F}$ test & $* *$ & $* *$ & $* *$ & $* *$ & $* *$ & $* *$ & $* *$ & $* *$ & $* *$ & $* *$ & NS & ** & $* *$ & $* *$ & $* *$ & ** & $* *$ & $* *$ \\
\hline \multicolumn{19}{|l|}{$\mathrm{N}$ levels ( $\mathrm{N}$ ) } \\
\hline N1 (125kg) & 57.62 & 61.25 & 98.62 & 98.12 & 99.38 & 95.00 & 58.38 & 50.50 & 318 & 313 & 3.11 & 3.31 & 8.59 & 7.95 & 6.42 & 6.01 & 2.17 & 1.94 \\
\hline N2 (100kg) & 55.38 & 62.50 & 96.25 & 95.00 & 96.25 & 91.25 & 50.42 & 47.73 & 277 & 279 & 2.96 & 3.15 & 7.29 & 6.79 & 5.44 & 5.13 & 1.85 & 1.66 \\
\hline N3 (75kg) & 56.62 & 59.62 & 92.88 & 94.50 & 86.25 & 89.38 & 49.75 & 43.62 & 249 & 255 & 2.87 & 3.03 & 5.90 & 5.99 & 4.39 & 4.61 & 1.50 & 1.38 \\
\hline F test & $*$ & $* *$ & $* *$ & ** & $* *$ & $* *$ & ** & $* *$ & $* *$ & $* *$ & $* *$ & ns & $* *$ & $* *$ & ** & ** & ** & $* *$ \\
\hline LSD $_{0.05}$ & 1.35 & 0.9 & 0.87 & 1.11 & 1.92 & 2.8 & 0.96 & 0.88 & 6.13 & 6.64 & 0.1 & ns & 0.22 & 0.21 & 0.18 & 0.18 & 0.06 & 0.06 \\
\hline \multicolumn{19}{|l|}{ Cultivars (C) } \\
\hline Sids 14 & 59.67 & 60.83 & 98.17 & 96.33 & 92.50 & 97.83 & 51.00 & 43.14 & 279 & 281 & 3.32 & 4.04 & 7.72 & 7.78 & 5.27 & 5.59 & 2.44 & 2.19 \\
\hline Shandawell 1 & 57.33 & 62.00 & 98.17 & 95.33 & 98.33 & 93.33 & 53.17 & 47.17 & 276 & 290 & 3.01 & 2.96 & 7.28 & 7.02 & 5.55 & 5.47 & 1.74 & 1.55 \\
\hline Giza 171 & 54.33 & 60.67 & 94.33 & 95.83 & 93.33 & 88.00 & 53.33 & 49.61 & 299 & 287 & 2.89 & 2.94 & 7.43 & 6.67 & 5.69 & 5.08 & 1.74 & 1.59 \\
\hline Gemmiza 12 & 54.83 & 61.00 & 93.00 & 96.00 & 91.67 & 88.33 & 53.89 & 49.22 & 271 & 271 & 2.71 & 2.70 & 6.60 & 6.16 & 5.15 & 4.87 & 1.45 & 1.30 \\
\hline F test & ** & ns & ** & ns & ** & ** & ** & $* *$ & $* *$ & $* *$ & ** & ** & $* *$ & ** & ** & ** & ** & $* *$ \\
\hline LSD $_{0.05}$ & 1.61 & ns & 1.39 & ns & 3.92 & 4.29 & 1.48 & 1.61 & 8.83 & 9.21 & 0.14 & 0.24 & 0.22 & 0.32 & 0.23 & 0.33 & 0.06 & 0.06 \\
\hline \multicolumn{19}{|l|}{ Interaction } \\
\hline DXN & $*$ & ** & ns & $*$ & ns & $*$ & ns & ns & $* *$ & $*$ & $* *$ & ns & ns & $* *$ & ns & $* *$ & $* *$ & $* *$ \\
\hline$D \times C$ & $* *$ & ns & ns & ns & ns & $*$ & $* *$ & $* *$ & ** & $* *$ & ns & ns & ** & $*$ & $* *$ & $* *$ & $* *$ & $* *$ \\
\hline $\mathrm{NXC}$ & $*$ & ns & ns & $* *$ & ns & ns & $* *$ & $* *$ & $* *$ & $* *$ & $* *$ & ns & $* *$ & $* *$ & $*$ & $* *$ & $* *$ & $* *$ \\
\hline$D \times N \times C$ & ns & ns & ns & ** & ns & ns & ** & $* *$ & $*$ & $* *$ & ** & ns & ns & ns & $\mathrm{ns}$ & ns & $* *$ & ** \\
\hline
\end{tabular}

*** significant at 0.05 and 0.01 level of probability, respectively.

S1 $=2018 / 2019$, S2 $=2019 / 2020$

ns= not significant.

(DH) Days to heading, (DM) Days to maturity, (PH) Plant height. 
Effect of two-factor interactions:

Sowing date $\mathbf{x}$ Nitrogen fertilization levels:

The sowing dates $x$ nitrogen fertilization levels (DxN) interaction had significant and highly significant effects, in the two seasons Table (1), on days to heading, number of spike $\mathrm{m}^{-2}$ and grain yield plot $^{-1}$, whereas it was highly significant on 100 - grain weight ( $\mathrm{g}$ ) in the first season and it was significant and significant on days to maturity, plant height, biomass and straw yield in the second season Table (1).

The two sowing dates $\times$ three $\mathrm{N}$ fertilization levels interaction was significant, in the two seasons Table (2), for the number of spikes $\mathrm{m}^{-2}$ and grain yield whereas it was significant. With increasing $\mathrm{N}$ level in plants sown on November $25^{\text {th }}$ was higher than those for later sowing dates on December $25^{\text {th }}$. Grain yield in the first sowing date with a high level from nitrogen fertilization gave 2.60 and $2.33 \mathrm{~kg} \mathrm{plot}^{-1}$ in the two seasons respectively.

Table 2. Mean values of studied characters as affected by sowing date $x$ nitrogen fertilization levels in the two seasons.

\begin{tabular}{|c|c|c|c|c|c|c|c|c|c|c|c|}
\hline \multirow[t]{2}{*}{ Treatment } & \multicolumn{2}{|c|}{$\mathrm{DH}$} & \multirow{2}{*}{$\begin{array}{l}\text { DM } \\
\text { S2 }\end{array}$} & \multirow{2}{*}{$\begin{array}{l}\mathrm{PH} \\
\mathrm{S} 2\end{array}$} & \multicolumn{2}{|c|}{ \#Spike $\mathrm{m}^{-2}$} & \multirow{2}{*}{$\frac{100 \mathrm{KW}(\mathrm{g})}{\mathrm{S} 1}$} & \multirow{2}{*}{$\begin{array}{c}\text { Biomass plot } \\
\text { S2 } \\
\end{array}$} & \multirow{2}{*}{$\begin{array}{c}\text { Straw yield plot }^{-1} \\
\text { S2 }\end{array}$} & \multicolumn{2}{|c|}{ Grain yield plot } \\
\hline & S1 & S2 & & & S1 & S2 & & & & S1 & S2 \\
\hline D1N1 & 63.75 & 62.25 & 102.50 & 102.50 & 372 & 360 & 3.40 & 9.71 & 7.38 & 2.60 & 2.33 \\
\hline D1N2 & 60.50 & 67.25 & 98.75 & 94.50 & 331 & 324 & 2.91 & 8.09 & 6.14 & 2.15 & 1.96 \\
\hline D1N3 & 63.50 & 64.25 & 97.25 & 93.75 & 316 & 310 & 2.70 & 7.56 & 5.80 & 1.93 & 1.76 \\
\hline D2N1 & 51.50 & 60.25 & 93.75 & 87.50 & 263 & 266 & 2.82 & 6.19 & 4.65 & 1.74 & 1.54 \\
\hline D2N2 & 50.25 & 57.75 & 91.25 & 88.00 & 224 & 233 & 3.02 & 5.48 & 4.12 & 1.55 & 1.36 \\
\hline D2N3 & 49.75 & 55.00 & 91.75 & 85.00 & 182 & 201 & 3.05 & 4.41 & 3.42 & 1.08 & 0.99 \\
\hline $\operatorname{LSD}_{0.05}$ & 1.56 & 1.20 & 1.34 & 3.33 & 7.41 & 8.01 & 0.22 & 0.28 & 0.24 & 0.08 & 0.10 \\
\hline
\end{tabular}

\section{Sowing date $x$ Cultivars:}

The sowing dates $x$ cultivars (DxC) interaction had significant and highly significant effects, in the two seasons Table (1), on number of grain spike ${ }^{-1}$, number of spike $\mathrm{m}^{-2}$, biological yield, straw yield and grain yield plot ${ }^{-1}$, whereas it was highly significant on days to heading in the first season and it was significant on plant height in the second season only Table (1). Concerning sowing dates $x$ cultivars (DxC) interaction Table (3), Sids 14 showed a progressive increase in those characters (biomass and grain yield plot $^{-1}$ in the two seasons) with recommended sowing date, whereas, the other three cultivars showed a significant increase when sowing in November $25^{\text {st }}$ compare to December $25^{\text {th }}$.

Table 3. Mean values of studied characters as affected by sowing date $\mathrm{x}$ bread wheat cultivars in the two seasons.

\begin{tabular}{|c|c|c|c|c|c|c|c|c|c|c|c|c|}
\hline \multirow[t]{2}{*}{ Treatment } & \multirow{2}{*}{$\begin{array}{c}\text { DH } \\
\text { S1 }\end{array}$} & \multirow{2}{*}{$\begin{array}{c}\mathrm{PH} \\
\mathrm{S} 2\end{array}$} & \multicolumn{2}{|c|}{ \#Grain Spike ${ }^{-1}$} & \multicolumn{2}{|c|}{ \#Spike $\mathrm{m}^{-2}$} & \multicolumn{2}{|c|}{ Biomass plot ${ }^{-1}$} & \multicolumn{2}{|c|}{ Straw yield plot ${ }^{-1}$} & \multicolumn{2}{|c|}{ Grain yield plot } \\
\hline & & & S1 & S2 & S1 & S2 & S1 & S2 & S1 & S2 & S1 & S2 \\
\hline D1C1 & 64.33 & 105.00 & 56.67 & 45.28 & 334 & 326 & 9.64 & 9.51 & 6.70 & 6.87 & 2.94 & 2.64 \\
\hline D1C2 & 63.00 & 100.00 & 56.00 & 48.00 & 332 & 324 & 9.26 & 8.45 & 7.09 & 6.50 & 2.17 & 1.95 \\
\hline D1C3 & 62.00 & 89.33 & 58.33 & 56.22 & 344 & 336 & 9.20 & 7.95 & 7.13 & 6.02 & 2.07 & 1.92 \\
\hline D1C4 & 61.00 & 93.33 & 52.78 & 51.11 & 348 & 339 & 8.93 & 7.91 & 7.19 & 6.35 & 1.73 & 1.55 \\
\hline D2C1 & 55.00 & 90.67 & 45.33 & 41.00 & 224 & 236 & 5.79 & 6.04 & 3.84 & 4.30 & 1.95 & 1.74 \\
\hline D2C2 & 51.67 & 86.67 & 50.33 & 46.33 & 220 & 256 & 5.31 & 5.59 & 4.00 & 4.44 & 1.31 & 1.15 \\
\hline D2C3 & 46.67 & 86.67 & 48.33 & 43.00 & 253 & 238 & 5.66 & 5.39 & 4.25 & 4.13 & 1.41 & 1.26 \\
\hline D2C4 & 48.67 & 83.33 & 55.00 & 47.33 & 194 & 203 & 4.27 & 4.42 & 3.11 & 3.38 & 1.16 & 1.04 \\
\hline $\operatorname{LSD}_{0.05}$ & 1.99 & 5.34 & 1.92 & 2.15 & 11.08 & 11.58 & 0.38 & 0.42 & 0.41 & 0.42 & 0.08 & 0.10 \\
\hline
\end{tabular}




\section{Nitrogen fertilization levels $x$ Cultivars:}

The nitrogen fertilization levels $x$ cultivars $(N \times C)$ interaction had significant and highly significant effects, in the two seasons, on number of grain spike ${ }^{-1}$, number of spike $\mathrm{m}^{-2}$, biological yield, straw yield and grain yield plot ${ }^{-1}$, whereas it was significant and highly significant on days to heading and 100-grain weight in the first season and it was highly significant on days to maturity in the second season only Table (1).

About nitrogen fertilization level $x$ cultivars $(N \times C)$ interaction Table (4), Sids 14 showed the highest and significant response in biomass, straw yield and grain yield to increased nitrogen fertilization level, in the two seasons, whereas, 100-grain weight(g) was not affected among three nitrogen fertilization levels. Wheat cultivars also, showed differential responses to increasing nitrogen fertilization levels in grain yield and yield components.

Table 4. Mean values of studied characters as affected by nitrogen fertilization levels $\mathrm{x}$ bread wheat cultivars in the two seasons.

\begin{tabular}{|c|c|c|c|c|c|c|c|c|c|c|c|c|c|}
\hline \multirow[t]{2}{*}{ Treatment } & \multirow{2}{*}{$\begin{array}{l}\mathrm{DH} \\
\mathrm{S1} \\
\end{array}$} & \multirow{2}{*}{\begin{tabular}{|l} 
DM \\
S2 \\
\end{tabular}} & \multicolumn{2}{|c|}{ \#Grain Spike ${ }^{-1}$} & \multicolumn{2}{|c|}{ \#Spike $\mathrm{m}^{-2}$} & \multirow{2}{*}{$\begin{array}{c}\text { 100-grain } \\
\text { weight(g) }\end{array}$} & \multicolumn{2}{|c|}{ Biomass plot ${ }^{-1}$} & \multicolumn{2}{|c|}{ Straw yield plot ${ }^{-1}$} & \multicolumn{2}{|c|}{ Grain yield plot } \\
\hline & & & S1 & S2 & S1 & S2 & & S1 & S2 & S1 & S2 & S1 & S2 \\
\hline N1C1 & 62.50 & 99.00 & 56.00 & 46.50 & 318 & 312 & 3.30 & 9.39 & 9.24 & 6.27 & 6.46 & 3.13 & 2.78 \\
\hline N1C2 & 57.00 & 95.50 & 56.50 & 44.00 & 321 & 318 & 3.26 & 8.66 & 7.91 & 6.66 & 6.13 & 2.00 & 1.78 \\
\hline N1C3 & 54.50 & 99.00 & 59.00 & 58.33 & 332 & 324 & 2.94 & 8.62 & 7.59 & 6.72 & 5.88 & 1.90 & 1.71 \\
\hline N1C4 & 56.50 & 99.00 & 62.00 & 53.17 & 300 & 297 & 2.94 & 7.68 & 7.07 & 6.03 & 5.59 & 1.65 & 1.48 \\
\hline N2C1 & 56.50 & 96.00 & 48.00 & 40.42 & 299 & 300 & 3.24 & 7.91 & 7.96 & 5.61 & 5.86 & 2.30 & 2.10 \\
\hline $\mathrm{N} 2 \mathrm{C} 2$ & 56.50 & 93.50 & 46.50 & 48.50 & 273 & 276 & 3.15 & 7.39 & 6.89 & 5.54 & 5.28 & 1.85 & 1.61 \\
\hline $\mathrm{N} 2 \mathrm{C} 3$ & 54.50 & 95.00 & 55.50 & 52.00 & 291 & 288 & 2.74 & 7.41 & 6.81 & 5.61 & 5.12 & 1.80 & 1.69 \\
\hline N2C4 & 54.00 & 95.50 & 51.67 & 50.00 & 246 & 251 & 2.73 & 6.44 & 5.51 & 4.99 & 4.25 & 1.45 & 1.25 \\
\hline N3C1 & 60.00 & 94.00 & 49.00 & 42.50 & 221 & 231 & 3.43 & 5.85 & 6.14 & 3.95 & 4.44 & 1.90 & 1.70 \\
\hline N3C2 & 58.50 & 97.00 & 56.50 & 49.00 & 234 & 276 & 2.62 & 5.80 & 6.27 & 4.44 & 5.00 & 1.36 & 1.27 \\
\hline N3C3 & 54.00 & 93.50 & 45.50 & 38.50 & 273 & 249 & 3.00 & 6.25 & 5.62 & 4.74 & 4.23 & 1.51 & 1.39 \\
\hline N3C4 & 54.00 & 93.50 & 48.00 & 44.50 & 267 & 266 & 2.45 & 5.68 & 5.91 & 4.43 & 4.76 & 1.25 & 1.16 \\
\hline $\operatorname{LSD}_{0.05}$ & 2.67 & 2.06 & 2.37 & 2.53 & 14.21 & 14.90 & 0.23 & 0.39 & 0.52 & 0.38 & 0.51 & 0.11 & 0.10 \\
\hline
\end{tabular}

Sowing date $x$ Nitrogen fertilization levels $x$ Cultivars:

The data in Table (1) is demonstrating that there is a significant effect for the interaction sowing date, nitrogen fertilization levels and cultivars on the number of spike $\mathrm{m}^{-2}$, the number of grain spike-1and grain yield characters under-study in the two seasons, days to maturity in the second season and 100-grain weight in the first season. Concerning sowing date $x$ nitrogen fertilization levels $x$ cultivars ( $D x N x C$ ) interaction Table (5), grain yield plot $^{-1}$ of Sids 14 showed a progressive increase in that character with two sowing dates and three nitrogen fertilization levels. 
Table 5. Mean values of studied characters as affected by sowing date $\mathrm{x}$ nitrogen fertilization levels $\mathrm{x}$ wheat cultivars in the two seasons.

\begin{tabular}{|c|c|c|c|c|c|c|c|c|}
\hline \multirow[t]{2}{*}{ Treatment } & \multirow{2}{*}{$\begin{array}{c}\text { DM } \\
\text { S2 }\end{array}$} & \multicolumn{2}{|c|}{ \# Spike $\mathrm{m}^{-2}$} & \multicolumn{2}{|c|}{ \# Grain Spike-1 } & \multirow{2}{*}{$\begin{array}{c}\text { 100-grain weight(g) } \\
\text { S1 }\end{array}$} & \multicolumn{2}{|c|}{ Grain yield plot ${ }^{-1}$} \\
\hline & & S1 & S2 & S1 & S2 & & S1 & S2 \\
\hline T1N1C1 & 103.00 & 366 & 354 & 65.00 & 52.00 & 3.45 & 3.90 & 3.50 \\
\hline T1N1C2 & 101.00 & 372 & 360 & 63.00 & 43.00 & 3.56 & 2.40 & 2.15 \\
\hline T1N1C3 & 103.00 & 378 & 366 & 64.00 & 65.67 & 3.28 & 2.20 & 1.97 \\
\hline T1N1C4 & 103.00 & 372 & 360 & 55.00 & 54.33 & 3.32 & 1.90 & 1.71 \\
\hline T1N2C1 & 99.00 & 357 & 348 & 52.00 & 39.83 & 3.40 & 2.50 & 2.33 \\
\hline T1N2C2 & 98.00 & 312 & 306 & 43.00 & 51.00 & 3.29 & 2.30 & 2.00 \\
\hline T1N2C3 & 99.00 & 330 & 324 & 63.00 & 59.00 & 2.54 & 2.10 & 2.05 \\
\hline T1N2C4 & 99.00 & 324 & 318 & 54.33 & 53.00 & 2.40 & 1.70 & 1.45 \\
\hline T1N3C1 & 97.00 & 279 & 276 & 53.00 & 44.00 & 3.06 & 2.40 & 2.10 \\
\hline T1N3C2 & 97.00 & 312 & 306 & 62.00 & 50.00 & 2.33 & 1.80 & 1.70 \\
\hline T1N3C3 & 98.00 & 324 & 318 & 48.00 & 44.00 & 3.07 & 1.90 & 1.75 \\
\hline T1N3C4 & 97.00 & 348 & 339 & 49.00 & 46.00 & 2.34 & 1.60 & 1.50 \\
\hline T2N1C1 & 95.00 & 270 & 270 & 47.00 & 41.00 & 3.14 & 2.35 & 2.05 \\
\hline T2N1C2 & 90.00 & 270 & 276 & 50.00 & 45.00 & 2.96 & 1.60 & 1.40 \\
\hline T2N1C3 & 95.00 & 285 & 282 & 54.00 & 51.00 & 2.60 & 1.60 & 1.45 \\
\hline T2N1C4 & 95.00 & 228 & 234 & 69.00 & 52.00 & 2.56 & 1.40 & 1.25 \\
\hline T2N2C1 & 93.00 & 240 & 252 & 44.00 & 41.00 & 3.08 & 2.10 & 1.86 \\
\hline T2N2C2 & 89.00 & 234 & 246 & 50.00 & 46.00 & 3.00 & 1.40 & 1.22 \\
\hline T2N2C3 & 91.00 & 252 & 252 & 48.00 & 45.00 & 2.93 & 1.50 & 1.32 \\
\hline T2N2C4 & 92.00 & 168 & 183 & 49.00 & 47.00 & 3.06 & 1.20 & 1.05 \\
\hline T2N3C1 & 91.00 & 162 & 186 & 45.00 & 41.00 & 3.80 & 1.40 & 1.30 \\
\hline T2N3C2 & 97.00 & 156 & 246 & 51.00 & 48.00 & 2.90 & 0.92 & 0.84 \\
\hline T2N3C3 & 89.00 & 222 & 180 & 43.00 & 33.00 & 2.93 & 1.12 & 1.02 \\
\hline T2N3C4 & 90.00 & 186 & 192 & 47.00 & 43.00 & 2.56 & 0.89 & 0.81 \\
\hline LSD $_{0.05}$ & 2.84 & 19.78 & 20.71 & 3.33 & 3.62 & 0.35 & 0.15 & 0.15 \\
\hline
\end{tabular}

\section{DISCUSSION}

Wheat sowing later subjected the crop to low soil temperatures, which resulted in poor emergence, as well as high temperatures during the grain filling stage, which may harm reproductive growth phases. According to (Upadhyay et al., 2015; Amal et al., 2016; and El Sayed et al., 2018), earlier wheat sowing at the optimal date resulted in greater growth of wheat plants, biomass accumulation and translocation to grains, and higher yield and yield characteristics. Similarly, improved grain yields were attained under optimal sowing conditions by (Said et al., 2012; El-Areed et al., 2017; Ren et al., 2019; Sayed et al., 2021). Sasani et al. (2020) found that negative effects of late sowing date on bread wheat performance through poor germination, which causes a decrease in growth of individual plants and reduces number of spike per plant under low temperatures when compared to recommended sowing date.

The appropriate nitrogen dose varies by region, depending on the nature of the land and environmental conditions. This can be attributed to the role that nitrogen, as an important macronutrient, plays in promoting plant growth and dry matter production, as well as improved photosynthesis, which helped to accumulate more biomass, which improved yield components, particularly the number of spikes/m2, 100-grain weight, and spikelet fertility. These observations were in addition to those published by (Ali et al., 2011; Enayat et al., 2013; Youssef et al., 2013; and Amal et al., 2016).

There are highly significant differences were obtained among the bread wheat cultivars for grain yield and yield component. This result indicates the presence of a clear degree of genetic variation that may contribute the most to adaptation and flexibility to diverse environmental conditions. Gomaa et al. (2018) confirmed that such significant main effects of the genotypes and their interactions with environments like sowing dates indicate that these genotypes carry genes with different additives and additives by additives effects which seemed unstable and tended to rank differently from the environment to another. 
Variations among wheat cultivars might be attributed to the genetic constitution of the cultivar. These results are in harmony with (Tahir et al., 2009; Hasina et al., 2012; Hassanein et al., 2012; Lak et al., 2013; Upadhyay et al., 2015 and Amal et al., 2016).

The high dose from nitrogen fertilization levels showed a progressive increase in these characters with recommended sowing date, whereas, the same trend was reported for differential response to nitrogen fertilization levels up to the sowing date, and this may be due to better plant establishment and growth on that recommended date that allowed plants to fully benefit from the higher application of similar results to nitrogen. This could be attributed to the potential of recommended sowing dates to benefit from higher $\mathrm{N}$ levels, as opposed to late-sown plants, which are subjected to a shorter growing season; similar findings were reported by (Amal et al., 2016). Days to heading and days to maturity vs. nitrogen fertilisation levels, on the other hand, decreased with postponing sowing; however, 100-grain weight did not differ significantly between the two sowing dates. These findings are consistent with those of (El-Gizawy 2009; Dagash et al., 2014; Alghabari and Al- Solaimani, 2015), who found that wheat responded differently to $\mathrm{N}$ fertilisation levels at varied sowing dates.

The cultivar Sids 14 was genetically stable, so gave the highest results under recommended and late sowing dates. The same differential response of cultivars to sowing date, On the other hand, days to heading and days to maturity, decreased with delaying sowing. Similar results have been reported by (Costa et al., 2013; Munsif et al., 2015; Shaalan et al., 2019; Moustafa et al., 2021)

Interaction between nitrogen fertilization levels and cultivars, Sids 14 gave the highest value under the three nitrogen fertilization levels for grain yield. Similar findings were reported by (Ali et al., 2005; Bakht et al., 2010; Amal et al., 2016; Mehasen et al., 2019). Who attributed the difference in response to increasing the level of nitrogen fertilization in wheat cultivars, to the ability of the cultivar's genetic composition to take advantage of the amount of nitrogen applied to the environmental conditions.

Many researchers revealed the importance of cultivar genotypic differences, as well as the recommended planting date. Similar results have been reported by (Ali et al., 2005; Bakht et al., 2010; Amal et al., 2016; Shaalan et al., 2019). Who attributed the difference in response to increasing the level of nitrogen application in wheat genotype to the ability of the cultivar's genetic composition to benefit from the amount of $\mathrm{N}$ applied to climate factors?

\section{CONCLUSIONS}

We can conclude that the cultivar Sids 14 produced the highest yields when sown on the recommended sowing date in this region. At Almarashda Agricultural Research Station, whereas, the results showed that postponing sowing significantly reduced all analyzed grain yield and its features when compared to the suggested sowing date of November $25^{\text {th }}$, which may be considered as the optimum time for obtaining high production of grains. All traits were improved by increasing $\mathrm{N}$ fertilisation from 75 to 125 kg N Fadden-1 (sandy soil).

\section{REFERENCES}

Abdel Nour, N.A. and Fateh, H., 2011. Influence of sowing date and nitrogen fertilization on yield and its components in some bread wheat genotypes. Egyptian Journal of Agricultural Research, 89(4), 1413-1433.

Alghabari, F., \& Al-Solaimani, S. G. (2015). Effect of sowing date and nitrogen fertilization on growth, yield and yield components of barley (Hordeum vulgare L.). International Journal of Innovation and Science Research, 18(1), 136-140.

Ali, A., Syed, A. A. W., Khaliq, T., Asif, M., Aziz, M., \& Mubeen, M. (2011). Effects of nitrogen on growth and yield components of wheat. (Report). Biology Science 3, 1004-1005.

Ali, H., Ahmad, S. H. A. K. E. E. L., Ali, H. I. N. A., \& Hassan, F. S. (2005). Impact of nitrogen application on growth and productivity of wheat (Triticum aestivum L.). Journal of Agricultural Science, 3, 216-218.

Amal G. M. Ali, Mohsen A. Omar, Ali I. Nawar and Sami Sh. El-Tabbakh (2016). Effect of sowing date and nitrogen fertilization level on growth and productivity of some durum and bread wheat varieties. Alexandria Science Exchange Journal. 37(4), 541-549.

Bakht, J., Shafi, M., Zubair, M., Khan, M. A., \& Shah, Z. (2010). Effect of foliar vs. soil application of nitrogen on yield and yield components of wheat varieties. Pakistan Journal of Botany, 42(4), 2737-2745.

Benin, G., Bornhofen, E., Beche, E., Pagliosa, E. S., Silva, C. L. D., \& Pinnow, C. (2012). Agronomic performance of wheat cultivars in response to nitrogen fertilization levels. Acta Scientiarum. Agronomy, 34(3), 275-283.

Costa, R., Pinheiro, N., Almeida, A. S., o Gomes, C., Coutinho, J., o Coco, J., ... \& Maçãs, B. (2013). Effect of sowing date and seeding rate on bread wheat yield and test weight under Mediterranean conditions. Emirates Journal of Food and Agriculture, 951-961.

Dagash, Y. M. I., Ahmed, I. S., \& Khalil, N. A. (2014). Effect of nitrogen fertilization, sowing methods and sowing dates on yield and yield attributes of wheat (Triticum aestivum L). Universal Journal of Plant Science, 2(6), 108-113. 
Ehdaie, B., \& Waines, J. G. (2001). Sowing date and nitrogen rate effects on dry matter and nitrogen partitioning in bread and durum wheat. Field Crops Research, 73(1), 47-61.

El-Areed Sh.R.M., M.M. Mohamed, Sh.Th.I. El-Sherif and A.S. Abd El-Hamed (2017). Response of some egyptian bread wheat cultivars to different sowing dates. Egyptian Journal of Plant Breeding, 21(7), 1297- 1307 (2017)

El-Gizawy, N. K. B. (2009). Effect of planting date and fertilizer application on yield of wheat under no till system. World Journal of Agriculture Science, 5(6), 777-783.

El Sayed A. A.; A. M. Omar; S. A. Elsaied and Basma E. El Samahey (2018). yield, yield traits and grain properties of some bread wheat cultivars as influenced by planting dates under Egyptian conditions. Journal Plant Production, Mansoura Univ., 9 (3), $233-239$.

Enayat, A., Lack, S., \& Modhej, A. (2013). Effect of different nitrogen rates on grain yield and grain growth of bread and durum wheat genotypes. International Journal of Agronomy and Plant Production, 4(11), 3076-3082.

Eslami, H., Navae, H. N., Alazmani, A. R., \& Shojaei, A. N. (2014). Effect of sowing dates and seeding density on yield of wheat (Triticumm aestivum L.). International Research Journal of Application and Basic Science, 8(7), 836-838.

FAO. (2020) 'Food and Agriculture Organization of United Nations' http://www.fao.org/statistics.

Gomaa, M.R., EL-Badawy, M.EL.M., El Hosary, A.A.A., El-Areed, Sh.R.M., Amer, A. (2018) Stability analysis for yield and its components in wheat. Egyptian Journal of Plant Breeding, 22(7), 1535-1550

Gomez, K. A., \& Gomez, A. A. (1984). Statistical Procedures for Agricultural Research. John Wiley \& Sons.

Hasina, G., Beena, S., Khan, A. Z., Umbarin, L., \& Khalid, A. (2012). Yield and yield contributing traits of wheat cultivars in relation with planting dates and nitrogen fertilization. Journal of Agricultural and Biological Science, 7(6), 386-395.

Hassanein, M. K., Elsayed, M., \& Khalil, A. A. (2012). Impacts of sowing date, cultivar, irrigation regimes and location on bread wheat production in Egypt under climate change conditions. Nature and Science, 10(12), 141-150.

Hefny Y. A. M. and Naheif E. Mohammed (2018). Behavior of some Bread Wheat Genotypes under Different Planting Dates and Nitrogen Fertilizer Levels in Sohag Governorate. Assiut Journal of Agricultural Science 49, 1-14.

IFPRI (2021) 'International food policy' Research institute online report August 2021. https://www.ifpri.org.

Iqbal, J., Hayat, K., Hussain, S., Ali, A., \& Bakhsh, M. A. A. H. A. (2012). Effect of seeding rates and nitrogen levels on yield and yield components of wheat (Triticum aestivum L.). Pakistan Journal of Nutrition, 11(7), 531.

Kiss, T., Balla, K., Bányai, J., Veisz, O., \& Karsai, I. (2014). Effect of different sowing times on the plant developmental parameters of wheat (Triticum aestivum L.). Cereal Research Communications, 42(2), 239-251.

Lak M., A. Farnia and M. Shaban (2013). Effect of different sowing dates on yield components of wheat (Triticum aestivum, L.) cultivars in Lorestan Provience. Iran Advances of Agricultural and Biology (4), 89-93.

Moustafa, E. S., El-Sobky, E. S. E., Farag, H. I., Yasin, M. A., Attia, A., Rady, M. O., ... \& Mansour, E. (2021). Sowing date and genotype influence on yield and quality of dual-purpose barley in a salt-affected arid region. Agronomy, 11(4), 717.

Munsif, F., Arif, M., Jan, M. T., Ali, K., \& Khan, M. J. (2015). Influence of sowing dates on phenological development and yield of dual purpose wheat cultivars. Pakistan Journal of Botany 47(1), 83-88.

Refay, Y. A. (2011). Yield and yield component parameters of bread wheat genotypes as affected by sowing dates. Middle East Journal of Scientific Research, 7(4), 484-489.

Ren, A. X., Min, S. U. N., Wang, P. R., Xue, L. Z., Lei, M. M., Xue, J. F., ... \& Yang, Z. P. (2019). Optimization of sowing date and seeding rate for high winter wheat yield based on pre-winter plant development and soil water usage in the Loess Plateau, China. Journal of Integrative Agriculture, 18(1), 33-42.

Said, A., Gul, H., Saeed, B., Haleema, B., Badshah, N. L., \& Parveen, L. (2012). Response of wheat to different planting dates and seeding rates for yield and yield components. ARPN Journal of Agricultural and Biological Science, 7(2), 138-140.

Sasani, S., Amiri, R., Sharifi, H.R., Lotfi, A. (2020) Impact of sowing date on bread wheat kernel quantitative and qualitative traits under Middle East climate conditions. Zemdirbyste-Agriculture, 107(3).

Sayed M. A., Mohamed T. Said, Mahmoud A. Elrawy (2021). Evaluation of Local Bread Wheat Cultivars for Grain Yield and Its Attributes at Different Sowing Dates under Assiut Conditions. Egyptian Journal of Agronomy, 43, 189- 206 (2021).

Shaalan, A., Attia, M. A., \& Hassaan, M. A. (2019). Response of Some Wheat Cultivars to Sowing Dates and Biofertilizers under North West Coast of Egypt. Egyptian Journal of Agronomy, 41(3), 313-324.

Shah, W. A., Khan, H. U., Anwar, S., \& Nawab, K. (2011). Yield and yield components of wheat as affected by different seed rates and nitrogen levels. Sarhad Journal of Agricultural, 27(1), 17-25.

Shahbandeh, M. (2021) Wheat-statistics \& facts (Mar. 23, 2021) - The Statistics Portal. [online] Statista. Available at: [Accessed 20 April 2021]. 
Shazma, A., Khattak, W. A., Muhammad, I., Saqib, B., Muhammad, S., \& Jehan, B. (2015). Effect of sowing dates and seed rates on the agro-physiological traits of wheat. Journal of Environment and Earth Science, 5(1), 135-141.

Statista. (2021) Egypt - wheat production 2020 | Statista. [online] Available at: [Accessed 20 April 2021].

Sun, H., Shao, L., Chen, S., \& Zhang, X. (2012). Effects of sowing time and rate on crop growth and radiation use efficiency of winter wheat in the North China Plain. International Journal of Plant Production, 7(1), 117-138.

Tahir, M., Ali, A., Nadeem, M. A., Hussain, A., \& Khalid, F. (2009). Effect of different sowing dates on growth and yield of wheat (Triticum aestivum L.) varieties in district Jhang, Pakistan. Pakistan Journal of life Society Science, 7(1), 66-69.

Tranavičienè, T., Šikšnianienè, J. B., Urbonavičiūtė, A., Vagusevičienè, I., Samuolienè, G., Duchovskis, P., \& Sliesaravičius, A. (2007). Effects of nitrogen fertilizers on wheat photosynthetic pigment and carbohydrate contents. Biologija, (4).

USDA (2020) Wheat cultivated area htttps://apps.fas. usda.gov/newgainapi/api/Report/Download Report By File Name? File Name=Grain\%20and\%20Feed\%20 Annual_Cairo_Egypt_03-15-2020 [Accessed 20 April 2021].

Upadhyay R. G., R. Ranjan and P. S. Negi (2015). Influence of sowing dates and varieties on productivity of wheat under midHimalayan region. Uttarakhand 33(2), 1905- 1909.

Copyright: (C) 2022 by the authors. Licensee EAR, EKB, Egypt. EAR offers immediate open access to its material on the grounds that making research accessible freely to the public facilitates a more global knowledge exchange. Users can read, download, copy, distribute, print or share a link to the complete text of the application under Creative Commons BY-NC-SA 4.0 International License.

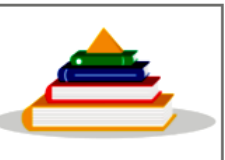




\section{تأثير موعد الزراعة والتسميد النيتروجينى على إمئى المحصول وبعض الصفات في أربعة أصناف من القمح الطريد على المريتري المصري}

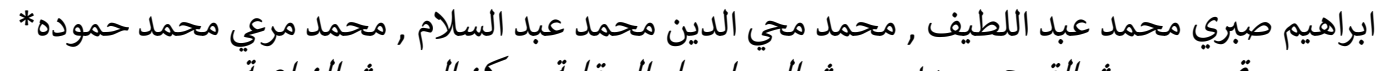

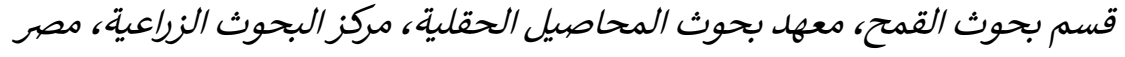

* بريد المؤلف المراسل: mmareei@yahoo.com *

$$
\text { الملخص مراس }
$$

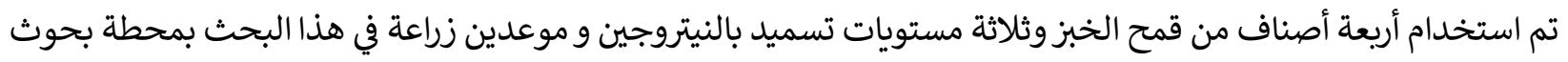

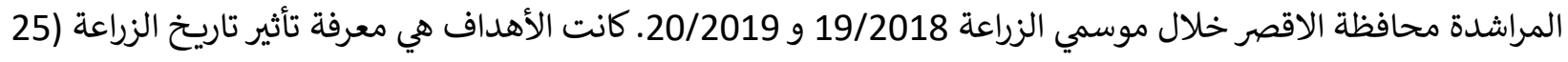

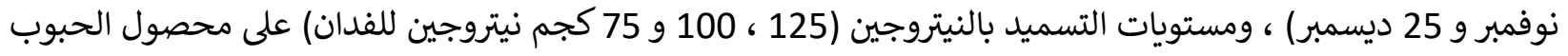

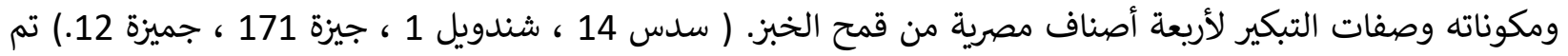

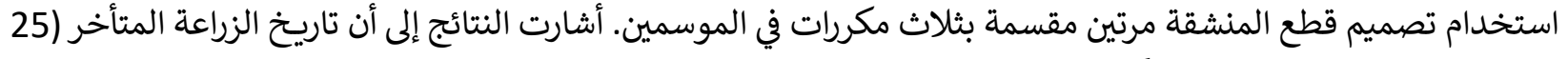

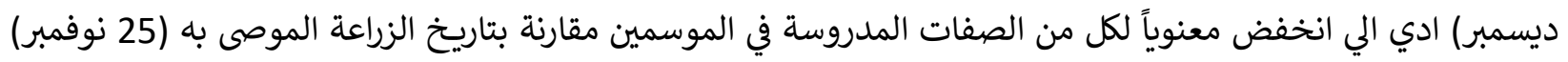

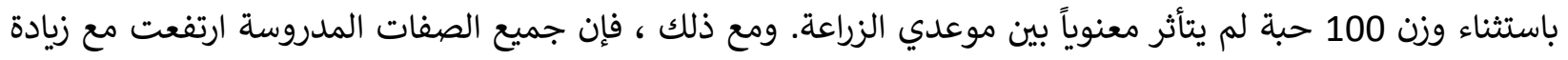

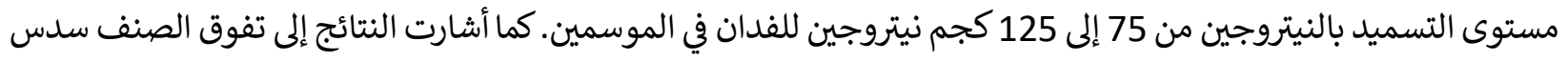

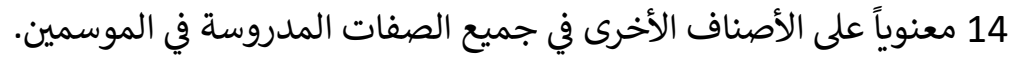

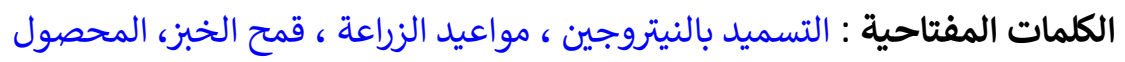

